In making the incision it is not necessary to use a sharp instrument. The friability of the lung often permits of the finger being used, in which case dangers are avoided and information procured which no other instrument could give. In my case bleeding was insignificant, and most surgeons have found that if it occurs it is easily arrested. Drainage takes place less by gravitation than by the expiratory efforts; but position can do much towards helping these. Similarly, position, aided by inspiratory efforts, will effectually distribute antiseptic applications, such as iodoform dust, eucalyptus oil, \&c., to subjacent parts of the lung, and their effect may be kept up by the use of volatile antiseptics in the dressing used. As in all my surgical cases for the last four years, 1 use large pads of cedar sawdust, to which I add creasote \&c.; these act as respirators, filtering and warming the air. I may add that the operation cannot be taxed with failure because a permanent cure is scarcely to be achieved, inasmuch as legitimate operative interference is necessarily delayed until the disease has made great headway, and the local symptoms, grave as they may be, are but the manifestations of a graver constitutional disease.

Kashmir Mission Hospital.

\section{CASE OF STRONGYLUS GIGAS.}

BY R. CANNON, L.K.Q.C.P., L.R.C.S.I., M.D. CHILI., LATE SURGEON, ROYAL MATY.

ON August 20th I was called to see a boy of twelve years of age suffering from febrile symptoms of three days' duration. He complained of headache, aching in the limbs, and general malaise. He had had epistaxis, his tongue was foul, and his bowels costive; temperature $39.50^{\circ} \mathrm{C}$; pulse 90 . The night before I saw him he could not micturate, and on the morning of my visit he had done so without difficulty. In the chamber-vessel, which he had used in the upright position, a worm had been seen. The "patio," or court of the house, was asphalted and dry, and it was quite impossible that any earth-worm could have been introduced by chance into this vessel. 1 take this to be a case of strongylus gigas, of which only seven cases at all trustworthy have, according to Davaine, been reported. The worm was in three parts, and was of a reddish colour, as if blood-stained. It measured about ten inches. Around the head could be seen prominences, as if tubercles or rudimentary eyes; some fine membranous filmo, as if of a delicate cyst, were adherent to the broken parts. The urine contained no blood or any deposits; it was of a darkish colour, but not more so than one sees in febrile states. I at once put the specimen into spirit and have not since extracted it, contenting myself with examining it with a lens. It does not appear to me to be an intescinal lumbricus, and I have not the slightest doubt that it issued from the boy's urethra. He was not aware of having passed anything unusual until the vessel was brought to him by his mother. There could be no object in deception of any kind. The boy was treated with salicylate of soda and with nightly doses of antipyrine, and after copious bleeding had taken place from the nostrils the headache and feorile symptoms were in a few days quite relieved, and the boy had no other troubles in connexion with the urinary organs.

We know that this parasite is found in the kidneys and urinary passages of such animals as the weasel, hare, ox, dog, wolf, \&c.; but in the present case the only animal that could have interfered would be the dog. I saw no dogs about tze "patio," and, besides, it would have been ridiculous to suppose that a dog would have had the sagacity to deposit his strongylus gigas in a chamber-vessel; moreover, on the previous night the boy had been unable to pass his urine, and the parasite must have occupied the urethra or blocked its entrance into the bladder.

Cases have been recorded in which intestinal worms have found their way into the bladder. This, of course, might easily occur in the female, but in the male the difficulty would be great. The boy, in this instance, was a quiet sensible lad, not by any means hysterical or a trickster, and 1 think the case from its rarity is very interesting and worthy of the fullest investigation. Of course the interest turns on this worm being a specimen of strongylus gigas or not, and this fact I have no means of deciding. I showed the specimen to my friend Dr. von Schroeders, of this city but he had no plates depicting the parasite. I also showed it to an American colleague, but, curiously enough, he had never heard of such a thing as strongylus gigas. Valparaiso, Chili.

\section{OCliniral a}

MEDICAL, SURGICAL, OBSTETRICAL, AND THERAPEUTICAL.

\section{A CASE OF EXOPHTHALMIC GOITRE TREATED BY THE CONTINUOUS CURRENT.}

Bx W. B. HA D DEN, M.D., M.R.C.P.

DRUGs are uncertain, and unfortunately often useless, in exophthalmic goitre. I therefore determined to try galvanism in this case, and the result, as will be seen, was very satisfactory.

The patient was a single young lady, aged twenty-eight, a professional nurse. She consulted me on Jan. 15th, 1886 . For nine months previously she had found difficulty in distinguishing the names of streets, and for three months her friends had notised that her eyes were prominent. She had remarked some fulness of the throat for two months. When I first saw her the eyes were markedly prominent and somewhat injected. The thyroid was large, mainly on the right side, but not pulsating. The pulse was 140. There was no cardiac bruit. She had frequent and excessive perspiration. There were constant efforts at deglutition, and she suffered from borborygmi. The bowels were regular. There was no derangement of the catamenia. She expressed herself as feeling pretty well in herself; but on being questioned said she had some dyspnoe and dysphagia. She had never suffered from any illness except measles. I ordereda constant battery of ten cells to be used night and morning. The negative pole was placed on the nape of the neck, and the positive over the thyroid gland and also over the eyeballs, the eyelids being closed. Each application did notextend beyond ten minutes. There was a marked improvement in a month.

On June 22nd she was practically well. The right eyeball and the right side of the thyroid were still slightly full. There was no palpitation, from which previously she had suffered, and the pulse was reduced to 96 . The perspiration and sensations of excessive heat had quite disappeared. I have seen her frequently since, and the improvement is maintained. She tells me that when her illness first began she used to sleep in cold weather with only a sheet over her. During the time she was under treatment her weight increased by more than one stone. No medicine was given except belladonna for two or three weeks; but this drug, which was prescribed at the very onset, was discontinued, as no beneficial result ensued. The battery was not used at this time.

Remarks.-The treatment of exophthalmic goitre by this method deserves a trial. I do not wish to dogmatise from one case; but I may mention that I have had quite recently the opportunity of seeing the beneficial effects of the continuous current in another patient.

Welbeck-street, $W$.

\section{ON A CASE OF TETANUS SUCCESSFULLY TREATED} WITH CHLORAL HYDRATE.

By J. HAwKGS, M.D.

I THINK the following notes on a case of idiopathic tetanus treated with chloral hydrate throughout the greater part of its duration may prove interesting, as indicating the almost specific effect of the drug and the large doses tolerated in this often intractable complaint.

A healthy country lad, aged thirteen, employed in outdoor work, was taken ill with symptoms of tetanus about a week before my attendance was requested on Nov. 16th. When I saw bim be was lying on his back in rigid opisthotonos; dorsal region and thorax prominently arched, and stretched towards the right side; bead drawn back; eyelids partly closed: lips retracted, exhibiting marked 
risus sardonicus; muscles of neck and trunk hard and board-like; lower extremities extencled; breathing hurried and shallow. The boy had been unable to sleep. The jaws were firmly clenched to within about a quarter of an inch. I ordered belladonna liniment to the spine, powdered jalap with calomel, and a sudorific mixture three times a day. As he resided at some distance from my house, two days elipsed before I saw him again, when his condition had undergone no change. The bowels had freely acted. Linseed-meal poultices sprinkled with turpentine were applied to the dorsal region, and ten grains of chloral hydrate, with twenty grains of bromide of potassium, were given every four hours.Tov. 21st: Has had two hours' sleep, the first he has had since the beginning of his illness. Decubitus natural; opisthotonos much relieved, but not disappeared. Countenance natural; lips no longer retracted, but the jaws are clenched as before. To continue treatment, and apply a mustard-and-linseed poultice to the nape of the neck.22nd: Slight improvement. - 2th: The chloral to be increased to twenty grains and the bromide of potassium to thirty, and taken every four hours. - 27th: Can open his mouth more freely, and speak distinctly, but the rigidity persists in the abdominal and thoracic muscles; the neck is easier. To apply linseed poultice with turpentine to the neck as before. To continue the treatment.Dec. 2nd: Lies placidly in bed ; answers questions distinetly; sleeps for two or three hours, but never more than three; bowels act regularly; takes semi-solid food. To continue the treatment.-6th: Is going on fairly well, but some rigidity continues, especially in the trunk; can move the feet freely. The chloral treatment was now suspended for four days, and henbane with foetid spirit of ammonia substituted, but no improvement followed.-10th: Ordered fifteen grains of chloral hydrate, twenty minims of tincture of lobelia, and twenty minims of compound tincture of cinchona, thrice daily.-13th : Belladonna plaster applied to the whole dorsal region. To continue the treatment.-17th : Has obtained further relief, the rigidity becoming less. To continue the mixture. Is wearing the plaster, which he feels to be beneficial.--22nd: Is altogether better. To continue the mixture and repeat the belladonna plaster.-24th : Is very comfortable, and almost convalescent.-29th: Was able to enjoy his Christmas dinner downstairs with the rest of his family. Appears to be fairly well. To discontinue the treatment.

Remarks.-This was a case of idiopathic tetanus brought on by exposure to wet and cold. It presented the symptoms of trismus very markedly, and there was absence of sleep for a long time. It appears to me that chloral alone or combined with bromide of potassium controlled the severity of the disease, and if it did not actually cure the malady it afforded time for nature to exert its recuperative power.

Northampton.

\section{SLRGICAL MISHAPS.}

By E. L. Hussex, F.R.C.S.E.

ONE of the cases mentioned by Mr. Teale reminds me of a case formerly under my care.

In $186 \mathrm{~L}$ a young lady applied to me with a small tumour behind the angle of the jaw on the right side. It was tough and aimost cartilaginous under examination, and the skin was generally adherent over the surface. The case had been seen by the late Mr. Hester and Mr. Owen of Oxford, and by Sir H. Acland. It was thought to be of a cystic nature, and the swelling had been injected with tincture of iodine. I cut through the substance in its whole thickness, and endeavoured to clear away the contents from each half; this could only be done to a very slight extent. The wound healed favourably. A second operation was undertaken some montls atterwards. The skin was divided, and separated without difficulty from the tumour. This now appeared to be about the size of a large wolnut and of a fibro-cellular structure. I cut off the exposed part, so as to clear the wound for a deeper dissection. Then, fixing a hook in the remining part, I endeavoured to draw it forwards. This I was unable to do. The attachment was evidently very deep; the skull itself moved with the motions of the hook. I cut off, as deeply as I could, the part of the tumour which was transfixed by the hook, and closed the wound. This healed as favourably as after the former operation. The lady afterwards married, and she died from phthisis more than twenty years after the operation. There was not any fresh growth of the tumour.
Being in communication with Mr. Cresar Hawkins at the time of the operation, I mentioned the case as a disagreeable piece of active surgery. He told me that Mr. Liston, in a similar case, found, upon the death of the patient, that the tumour had its origin in the base of the skull. Oxford.

\section{IIYDATID OF LIVER TREATED BY PUNCTURE; COMPLETE RECOVERY.}

By FredK. A. A. SMith, M.D.

Mrs. K-, aged forty-eight, struck her right side against the kitchen table about five months ago. She did not think anything about the accident, but soon afterwards felt a pain in the right side, which gradually enlarged and extreme emaciation set in. Cancer was diagnosed by several medical men, and one thought the ribs were fractured. When I saw the patient, she was extremely weak and emaciated, and looked like a woman dying of cancer. On examination the ribs of the right side were found very prominent, with bulging of the intercostal spaces. Percussion dulness extended over the median line and downwards to nearly three inches below the ribs. The tumour felt firm and smooth, and gave one the impression of an enlarged liver. At a spot, the size of a florin, an inch below the margin of the lower ribs and two inches to the right of the median line, slight fluctuation was felt. Diagnosing the case as one of either abscess or hydatid cyst, I plunged a No. 1 trocar and cannula into the centre of the fluctuating spot, in a direction upwards and backwards, and drew off about six ounces of limpid, straw-coloured fluid. A small piece of plaster was placed over the puncture and a towel tied tightly round the abdomen. Nothing more was done, and the patient got rapidly well and is still alive. The only precautions I took were to stretch the skin, so as to make the opening valvular and arrest the How of liquid before the cyst was entirely emptied; thus no air was allowed to enter.

The interesting part of this case was the distinct history of a blow, and the rapid enlargement of the tumour and extreme emaciation. The fluid was examined carefully under the microscope, but no hooklets were detected. Cheltenham.

\section{g. athrux}

\section{HOSPITAL PRACTICE, BRITISH AND FOREIGN.}

Nulla autem est alia pro certo noscendi via, nisi quamplurimas et morborum et dissectionum historias, tum aliorum tum proprias collectas habere, et inter se comparare.-MorgaGNI De Sed. et Caus. Morb." lib. iv. Procmium.

\section{ST. THOMAS'S HOSPITAL.}

SUPRA-PUBIC LITHOTOMY IN A MAN AGED SEVENTY-TWO; CURE; SUBSEQUENT DEATH FROM APOPLEXY; RAMARKS.

(Under the care of Mr. JoHN CROFT.)

THE following case is one of those in which the operation which was performed is specially advantageous. There were two large stones, an enlarged prostate, and a patient who was in a very poor state of general health. He was not in a condition to bear the prolonged administration of an anæsthetic, or the manipulation which would have been called for had the size of the stones permitted of lithotrity ; therefore no very accurate measurement was taken of the stones before operation, the supra-pubic method being so clearly indicated.

J. T-_-, aged seventy-two, a Jabourer, was admitted into Edward ward on July 1'th. About twelve years ago he noticed pain at the end of the penis on micturating; during the last two or three years the pain has increased. Micturition is and has be $n$ very frequent, he not being able to hold his urine for mor 3 than two hours. Has on several occasion had catheters passed, but has not suffered from retention of urine. On examination per rectum the prostate 